Original article

\title{
Antibacterial activity of an essential oil and various extracts of the medicinal plant Thymus hirtus sp. algeriensis Boiss. \& Reut
}

\author{
Yamina Bouatrous \\ Laboratory of Genetics, Biotechnology and Valorization of Bio-Resource (GBVB), Department of Natural Sciences \\ and Life, Faculty of Exact Sciences and Natural Sciences and Life, Mohamed Khider University, Biskra, Algeria
}

Received October 13, 2019: Revised December 13, 2019: Accepted December 15, 2019: Published online December 30, 2019

\begin{abstract}
Bacteria are most often implicated in cases of food poisoning and the extensive use of chemical, antibacterial agents in the medication leads to the selection of resistant bacterial strains. The essential oils of medicinal and aromatic plants can be used as an alternative for the treatment of infectious diseases and for the protection of food against any alteration. This study was carried out in order to examine in vitro the antibacterial activity of the essential oil of Thymus, ethanolic and aqueous extracts are tested on pathogenic bacteria: (Escherichia coli, Staphylococcus aureus, Pseudomonas aeruginosa and Salmonella entertica), responsible for the toxins food infections in Algeria.

The essential oil revealed variable antibacterial activities against the bacterial strains tested except the Pseudomonas aerugionsa strain. However, the ethanolic extract shows particularly remarkable antibacterial activity on Staphylococcus aureus only with a inhibition zone of the order of $(10.91 \pm 0.05)$. The aqueous extract showed no antibacterial activity. The evaluation also of the association effect of the essential oil of an aromatic plant (Thymus algeriensis) and an antibiotic gentamycin on four bacterial strains, one gram-positive and the other three gram-negative, gives us very important results regarding the association between thyme essential oil and gentamycin which appeared more effective compared to the use of each separate compound.
\end{abstract}

Key words: Medicinal plants, traditional phytotherapy, antibacterial activity, Thymus hirtus sp. algeriensis

\section{Introduction}

For centuries and even millennia, our ancestors have used plants to relieve their pain, heal their ailments and heal their wounds. From generation to generation, they have passed on their simple knowledge and experiences, striving when they could to write them down (Tabuti et al., 2003). Thus, even today, despite the phenomenal development of the pharmaceutical and chemical industry, popular interest in herbal medicine has never ceased to evolve.

Medicinal plants contain a large number of active molecules of multiple interests used in industry, food, cosmetology and dermopharmacy. Among these molecules are coumarins, alkaloids, phenolic acids, tannins, lignins, terpenes and flavonoids (Bahorun, 1997). Flavonoids potentially have biological, anti-inflammatory, anti-carcinogenic, antimicrobial and antioxidant activities (Atik Bekkara et al., 2007).

In developing countries, between 70 and $95 \%$ of the population uses medicinal plants for primary care because of a lack of access to

Author for correspondence: Dr. Yamina Bouatrous

Laboratory of Genetics, Biotechnology and Valorization of Bio-Resource (GBVB), Department of Natural Sciences and Life, Faculty of Exact Sciences and Natural Sciences and Life, Mohamed Khider University, Biskra Algeria, BP145 RP, 07000-Algeria

E-mail: y.bouatrous@univ-biskra.dz; bouatrousyamina@yahoo.fr Tel.: +21333724498

Copyright (C) 2019 Ukaaz Publications. All rights reserved.

Email: ukaaz@yahoo.com; Website: www.ukaazpublications.com prescribed medicines but also because the plants have been able to demonstrate real efficacy. It is estimated that at least $25 \%$ of all modern medicines are derived directly or indirectly from plants, thanks to the application of modern technologies to traditional knowledge.

According to the FAO (1996), Professor Auguste Chevalier, Burkina Faso's first botanist explorer, states that there is not a plant on earth that does not have some connection with human needs and serves some part of its table, its clothing, its roof, its pleasures, its remedies or at least its home. This statement proves that it is necessary to understand people's relationships with the environment and more specifically with plants. It is with this in mind that we are interested in a study of the antibacterial activity of the species Thymus hirtus sp algeriensis.

The Algerian flora with its 3000 species belonging to several botanical families, 15\% of which are endemic (Quezel and Santa, 1963), remains little explored both pharmacologically and phytochemically.

The valorization of medicinal plants of the national flora will be of great contribution for the Algerian pharmaceutical industry and will have a definite economic impact.

The genus Thymus includes a large number of species, subspecies and varieties of wild plants. Several of these species are characteristic of the Mediterranean area. They are used in a fresh or dry state as culinary plants. Their essential oils are widely used in alternative medicine due to their antiseptic, antispasmodic and antimicrobial properties (Van Den Broucke and Lemli, 1981; Panizzi et al., 1993). 
Algerian thyme has several Arabic vernacular names, djertil, hamria, hamzoucha khieta mezouqach. Is a bitter astringent, stomachic, diaphoretic, antispasmodic and stimulating. It uses the best buds and young flowering branches. Thym contains essential oils whose main components are thymol and carvacrol, tannins, bitter principles, saponins and plant antiseptics (Beloued, 2009).

The choice of this plant was based on the importance of its "Lamiaceae" family on the one hand and on its known and frequent traditional use in the population studied on the other.

\section{Materials and Methods}

\subsection{Plant material}

The plant Thymus hirtus sp algeriensis was harvested in March 2019, in the commune of El Kantara (Wilaya of Biskra). Voucher specimen are deposited in the herbium of the Department of Nature and Life Sciences, University of Biskra, Algeria under the code LAM-023-3-2019.

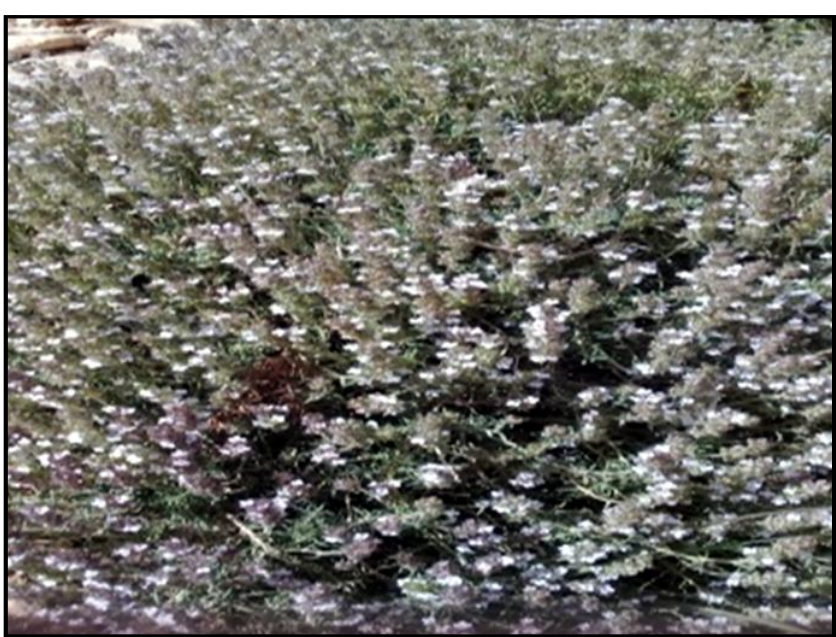

Photo 1: The plant Thymus hirtus sp. algeriensis

The aerial part of the plant (leaves, stems and flowers) dried in a dry and ventilated place, away from direct sunlight and at room temperature for a few days. After drying, the plant was manually crushed and stored in paper bags until it was used.

\subsection{Extraction of essential oils}

The extraction of essential oils was carried out by hydrodistillation in a Clevenger apparatus. A quantity of $100 \mathrm{~g}$ of dry plant material is placed in a flask heater with $1000 \mathrm{ml}$ of distilled water and then brought to a boil (simple boiling has been used) for $4 \mathrm{~h}$. The essential oils are recovered in a small opaque bottle and stored at $4^{\circ} \mathrm{C}$.

\subsubsection{Calculation of essential oil yield}

The essential oil yield is the ratio between the weight of oil and the weight of the plant (Afnor, 1986). It is expressed as a percentage and calculated by the following formula:

Yield $=\mathrm{M}^{\prime} / \mathrm{M} .100$

Yield : Essential oil yield expressed as a percentage (\%).

M' : Mass of the essential oil obtained in grams (g).

M : Mass of dry plant matter used in grams (g).

\subsection{Preparation of extracts}

\subsubsection{Ethanolic extract}

It is a solid-liquid extraction. The principle consists in dissolving the active principle inside the solid and dragging it out using a solvent (Ribereau-Gayon, 1968). Ethanol was used as a solvent.

A test sample of $100 \mathrm{~g}$ of powder was macerated in $1000 \mathrm{ml}$ of ethanol for $24 \mathrm{~h}$; after filtration the extracts are dried with rotavapor, to remove the ethanolthe, the operation is repeated 3 times.

\subsubsection{Aqueous extract}

An aqueous maceration was also carried out on $5 \mathrm{~g}$ of powder with $50 \mathrm{ml}$ of distilled water and placed under agitation for $24 \mathrm{~h}$. After filtration, the extracts are dried with rotavapor, to remove the water.

\subsubsection{Calculation of dry extract yields}

The dry matter yield of the plants was determined by calculating the following ratio:

Yield $=\mathrm{M}^{\prime} / \mathrm{M} .100$

Yield : Yield in extract expressed as a percentage (\%).

M' : Mass of the extract obtained in grams (g).

M : Mass of dry plant matter used in grams (g).

\subsection{Evaluation of antibacterial activity}

Two different methods are used to evaluate the antimicrobial effect of the different crude extracts:

- The method of diffusion from a paper disc, that allows the detection of the antimicrobial activity of the different extracts.

- The micro-dilutions method, which aims to determine, MICs (minimum inhibitory concentrations) from a range of product concentrations, in the culture medium.

\subsubsection{Antibacterial activity}

The principle of evaluating the antimicrobial activity of extracts consists in performing a microbial culture on a solid medium, in the presence of discs impregnated with different extracts. If the extracts have antibacterial activity, an inhibition zone around the disc will be observed. The diameter of this inhibition zone is proportional to the effectiveness of the antimicrobial activity of the test extract (Fattouch et al., 2007).

The antibacterial activity of essential oils and extracts was carried out using the disc diffusion method on a solid culture medium (AitOuazzou et al., 2012).

\subsubsection{The bacterial strains used}

Antibacterial tests were performed on clinical and reference strains.

Reference strains

Escherichia coli ATCC 25922

Staphylococcus aureus ATCC 25923

Pseudomonas aeruginosa ATCC 27853

Clinical strains

Salmonella entertica 
The bacterial strains used in this work got from the laboratory of the Batna Cancer Centre Hospital, Algeria.

\subsubsection{Replicating bacterial strains}

The different bacterial strains were transplanted by the nutrient agar stripe method and incubated at $37^{\circ} \mathrm{C}$ for $24 \mathrm{~h}$ to obtain young and isolated bacterial colonies used to prepare the inoculum.

\subsubsection{Preparation of bacterial inoculum}

The inoculum was prepared by sampling well isolated and identical bacterial colonies from a tube containing $9 \mathrm{ml}$ of sterile physiological water. The inoculum density was adjusted to $0.5 \mathrm{Mc}$ Farland or an optical density of 0.08 to 0.10 at $625 \mathrm{~nm}$ (corresponding to approximately $108 \mathrm{CFU} / \mathrm{ml}$ ) (Casfm, 2015).

\subsubsection{Seeding of bacteria}

Seeding is carried out in Petri dishes containing Mueller-Hinton MH agar (the most commonly used medium for antibacterial agent susceptibility testing) and left for 15 min to solidify, and with a swab, soaking it in the bacterial suspension, then seeding the entire surface of the stippled dishes from top to bottom, in tight streaks using a swab (Kechkar, 2008).

\subsubsection{Preparation of the various extracts}

The essential oil, ethanolic extract and aqueous extract have been prepared using DMSO which is inert on bacterial activity.

\subsubsection{Disk deposits}

After sowing, diffusion discs (Watman $\mathrm{N}^{\circ} 3$ ) paper sterilized by autoclaving at $120^{\circ} \mathrm{C}$ for $15 \mathrm{~min}$ are placed on the surface of the boxes sown with sterile pliers; these discs are injected by 20 microlitres of essential oil and extracts (Gulluce et al., 2003). Two controls were performed: A DMSO impregnated disc serves as a negative control and a gentamicin disc serves as a positive control. All tests were repeated three times.

The boxes are kept at laboratory temperature for $30 \mathrm{~min}$ to allow for pre-diffusion. Then they are incubated at $37^{\circ} \mathrm{C}$ for $24 \mathrm{~h}$.

\subsubsection{Reading the result}

The diameters of the inhibition zones are measured using a caliper $(\mathrm{mm})$, outside the closed box, the manipulations are repeated 3 times to ensure that the method runs smoothly (Joffin and Layeral, 2006).

\subsection{Inhibition zones}

The results of the inhibition zones of the strains tested are shown in the following Table.

Table 1: Diameter (mm) of the inhibition zones

\begin{tabular}{|c|c|c|c|c|}
\hline & inhibition zon & & & \\
\hline strain & Essential oil & Ethanolic extract & Aqueous extract & Gentamycin \\
\hline $\begin{array}{l}\text { S. aureus } \\
\text { E. coli } \\
P . \text { aeruginosa } \\
\text { S. enterica }\end{array}$ & $\begin{aligned} 11.52 & \pm 0.41 \\
11.53 & \pm 0.43 \\
& - \\
12.51 & \pm 0.19\end{aligned}$ & $\begin{aligned} 10.91 & \pm 0.05 \\
& - \\
& - \\
& -\end{aligned}$ & $\begin{array}{l}\text { - } \\
- \\
-\end{array}$ & $\begin{array}{l}33.37 \pm 0.59 \\
26.47 \pm 1.09 \\
32.53 \pm 0.22 \\
27.66 \pm 2.22\end{array}$ \\
\hline
\end{tabular}

(-) means that there is no inhibition zone

These values represent the mean \pm standard deviation

\subsubsection{Liquid micro-dilutions method}

Minimum Inhibitory Concentrations (MICs) and Minimum Bactericidal Concentrations (MBCs) were determined using the micro-dilution technique with Muller Hinton broth (Nccls, 2000).

\subsubsection{Determination of the Minimum Inhibitory Concentration (MIC)}

Microdilution is generally performed in 96-well plates with a rounded bottom. The bacterial suspensions were diluted with broth and distributed in these plates (Kahlmeter and Turnidge, 2012).

A stock solution of the essential oil and ethanolic extract was prepared in the DMSO at $10 \%$, then serial dilutions of the essential oil and ethanolic extract were made in the 96 -well microplate. $90 \mu$ lof Mueller Hinton broth was incorporated and then inoculated with $10 \mu \mathrm{l}$ of standardized bacterial inoculum. All tests are repeated three times. A positive control containing $10 \mu \mathrm{l}$ of inoculum and $190 \mu \mathrm{l}$ of Muller Hinton Broth, and a negative control containing $100 \mu$ l of essential oil or ethanolic extract dissolved in 10\% DMSO and $100 \mu$ l of Muller Hinton Broth without inoculum). The plates were covered and incubated at $37^{\circ} \mathrm{C}$ for $24 \mathrm{~h}$.

The Minimum Inhibitory Concentration (MIC) has been defined as the minimum concentration of extract for which no growth visible to the naked eye is observed.

\section{Results}

\subsection{Yield}

According to the results shown in (Figure 1), it has been observed that the yield of essential oils of the species Thymus hirtus sp algeriensis is $0.5035 \%$, While the yield of the aqueous extract of this species is $5.20 \%$ which is lower than the ethanolic extract which is $5.75 \%$.

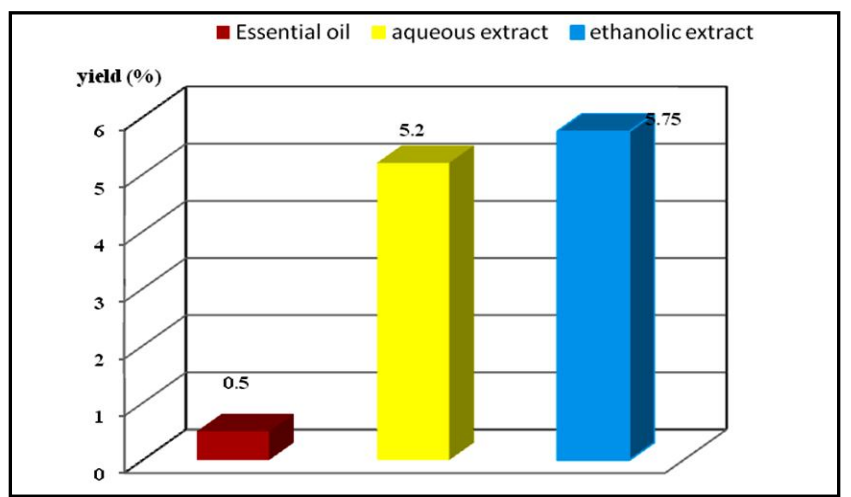

Figure 1: The plant Thymus hirtus sp. algeriensis 


\subsection{Sensitivity of bacterial strains}

The reading is made by measuring the diameter of the inhibition zone around each disc using a caliper in ( $\mathrm{mm}$ ) (Table 2). The results are expressed by the diameter of the inhibition zone and can be symbolized by signs based on the sensitivity of the strains (Ponce et al., 2003).
Not sensitive or resistant (-): diameter $<8 \mathrm{~mm}$.

Sensitive (+): diameter between 9 and $14 \mathrm{~mm}$.

Very sensitive $(++)$ : diameter between 15 and $19 \mathrm{~mm}$.

Extremely sensitive $(++++)$ : diameter $>20 \mathrm{~mm}$.

The sensitivity results of bacterial strains are shown below:

Table 2: Sensitivity of bacterial strains

\begin{tabular}{|l|c|c|c|c|}
\hline & sensitivity & \multicolumn{3}{|c|}{ Gentamycin } \\
\hline strain & Essential oil & Ethanolic extract & Aqueous extract & +++ \\
\hline S. aureus & + & + & - & +++ \\
E. coli & + & - & - & ++ \\
aeruginosa & - & - & - & ++ \\
S. enterica & + & - & ++ \\
\hline
\end{tabular}

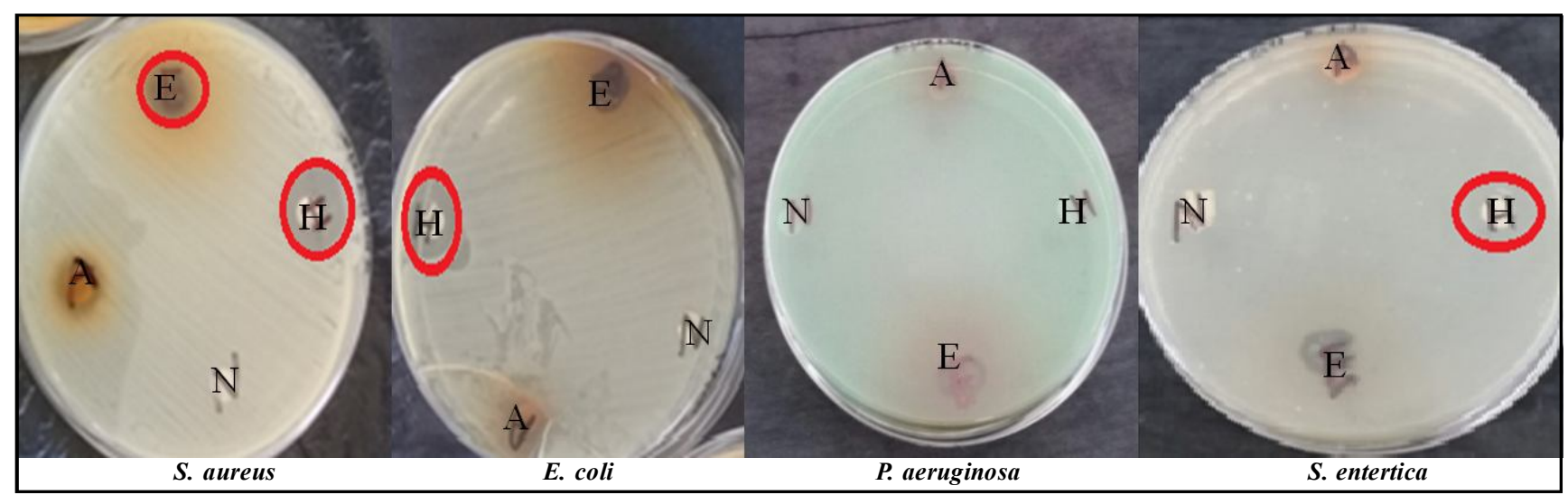

Photo 2: Aromatogram result of the different extracts

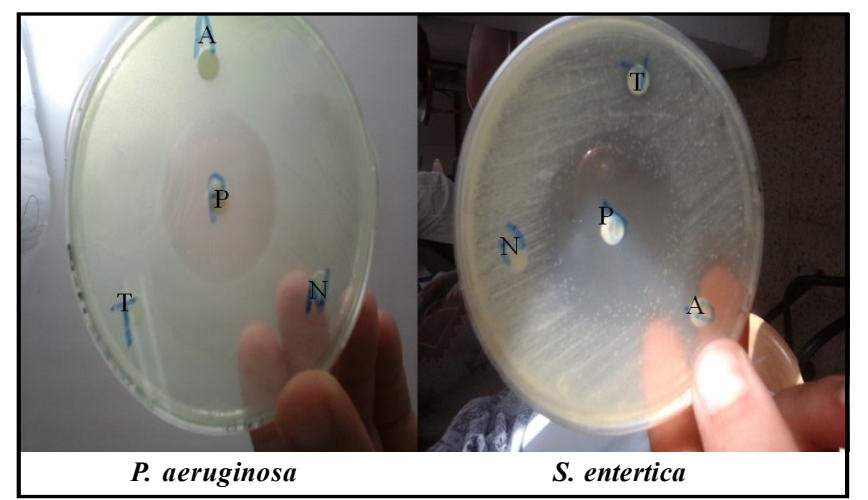

Photo 3: Gentamycin inhibition zone.

According to (Tables 1 and 2), which showed the inhibition zones of T. hirtus, the antibiotic gentamicin has distinct effects on the bacteria tested, compared to the other extracts of the plant studied.

For the results of the essential oil, it was observed that the susceptible strains, S. aureus, E. coli and S. enterica have inhibition zones of $11.52,11.53$, and $12.51(\mathrm{~mm})$, respectively. On the other hand, the $P$. aeruginosa strain has been shown to be resistant.

The ethanolic extract reacted positively only on the $S$. aureus strain with a diameter of $10.91 \pm 0.05$, so this strain is sensitive.
For aqueous extracts, the results showed that these extracts have no antibacterial effect against all bacterial strains, tested either grampositive or gram-negative.

\subsection{Minimum inhibitory concentration}

From Table 3 which presents the Minimum Inhibitory Concentrations (MICs) of T. hirtus. The oil was found to be active to varying degrees against all bacterial strains tested, except $P$. aeruginosa, E. coli and $S$. entertica had MICs of $50 \mathrm{mg} / \mathrm{ml}$, while $S$. aureus had an MIC of 25 $\mathrm{mg} / \mathrm{ml}$. The ethanolic extract reacted positively only against $S$. aureus at a MIC of $25 \mathrm{mg} / \mathrm{ml}$.

Table 3: The minimum inhibitory concentration (MIC)

\begin{tabular}{|l|c|c|}
\hline & \multicolumn{2}{|c|}{ MIC $(\mathbf{m g} / \mathbf{m l})$} \\
\hline strain & Essential oil & Ethanolic extract \\
\hline S. aureus & $25 \pm 0.33$ & $25 \pm 0.22$ \\
E. coli & $50 \pm 0.25$ & - \\
P. aeruginosa & - & - \\
S. enterica & $50 \pm 0.45$ & - \\
\hline
\end{tabular}

\subsection{Minimum bactericidal concentration}

According to Table 4 which presents the minimum bactericidal concentrations (MBCs) of $T$. hirtus, it has been shown that the oil was only active against $S$. entertica strain by CMB of $100 \mathrm{mg} / \mathrm{ml}$ and $S$. aureus strain by a CMB concentration of $50 \mathrm{mg} / \mathrm{ml}$.

The ethanolic extract reacted positively only against $S$. aureus with a CMB of $50 \mathrm{mg} / \mathrm{ml}$. 
Table 4: The Minimum bactericidal concentration (MBC)

\begin{tabular}{|l|c|c|}
\hline & MBC \\
\hline strain & Essential oil & Ethanolic extract \\
\hline S. aureus & $50 \pm 0.23$ & $50 \pm 015$ \\
E. coli & - & - \\
P. aeruginosa & - & - \\
S. enterica & $100 \pm 048$ & - \\
\hline
\end{tabular}

3.6 Test of the effect of the combination of essential oil of Thymus algeriensis and gentamycin and two

In order to test the effect of the combination of the essential oil of $T$. algeriensis and the antibiotic gentamycin on the four bacterial strains, the two extracts were mixed, concentration-by-concentration (each dilution with the corresponding one). The results of this test are shown in Table 5.

Table 5: Inhibition zone of mixture between essential oil and gentamycin

\begin{tabular}{|c|c|c|c|c|c|}
\hline & \multicolumn{4}{|c|}{ inhibition zone } \\
\hline & & S. aureus & E. coli & P. aeruginosa & S. enterica \\
\hline mixture between essential oil and gentamycin & $\begin{array}{l}M S \text { Mother Solution } \\
1 / 2 \\
1 / 4 \\
1 / 8\end{array}$ & $\begin{array}{l}22.52 \pm 0.36 \\
18.21 \pm 0.43 \\
15.23 \pm 0.425 \\
13.28 \pm 0.14\end{array}$ & $\begin{array}{l}25.91 \pm 0.14 \\
16.82 \pm 0.05 \\
14.32 \pm 0.10 \\
10.23 \pm 0.09\end{array}$ & $\begin{aligned} 10.78 & \pm 0.11 \\
8.92 & \pm 0.14 \\
& / \\
& /\end{aligned}$ & $\begin{array}{l}18.37 \pm 0.59 \\
15.47 \pm 10.08 \\
12.53 \pm 0.12 \\
10.23 \pm 0.06\end{array}$ \\
\hline
\end{tabular}

According to Table 5, it was found that the mixture between T. hirtus essential oil and gentamycin antibiotic gave a stronger activity compared to the use of each single compound, regardless of the bacterial strain treated. Regarding the effect of essential oil on the bacterial strain, $P$. aeruginosa which appeared resistant, becomes sensitive in the case of use of mixture, especially in the use of the mother solution (Table 6).

Table 6: Sensitivity of bacterial strains

\begin{tabular}{|c|c|c|c|c|c|}
\hline & \multicolumn{4}{|c|}{ inhibition zone } \\
\hline & & S. aureus & E. coli & P. aeruginosa & S. enterica \\
\hline mixture between essential oil and gentamycin & $\begin{array}{l}M S \text { Mother Solution } \\
1 / 2 \\
1 / 4 \\
1 / 8\end{array}$ & $\begin{array}{l}+++ \\
++ \\
++ \\
+\end{array}$ & $\begin{array}{l}+++ \\
++ \\
+ \\
+\end{array}$ & $\begin{array}{l}+ \\
+ \\
- \\
-\end{array}$ & $\begin{array}{l}++ \\
++ \\
+ \\
+\end{array}$ \\
\hline
\end{tabular}

\section{Discussion}

Recent scientific research has focused on the study of novel plantderived antioxidants and antibacterials, particularly polyps that replace synthetic substances (Bougatef et al., 2009).

Similarly, treatment with conventional antibiotics is associated with several effects, adverse events such as increased risk of bleeding linked to linezolid, the emergence important bacterial resistant species as well as the disadvantages associated with the treatment with antibiotics incompatible with the external administration of the patient such as extension of hospital stay and ex position to infections nosocomial (Song, 2008).

Concerning the yield of aqueous extracts, it was found in this study that it is lower than those mentioned in the work of Zeghib (2013), (Asmaa and Laaribyia , 2017) who obtained a yield equal to $10.52 \%$. While the yield of ethanol extract is higher than those mentioned in the work of Tamert (2007), who obtained a yield equal to $4.33 \%$.

Many factors influence the yield, grade, physicochemical characteristics and chemical composition of essential oils such as species, environmental conditions, extraction technique, drying period and harvesting medium, cultural practices and the age of plant material (Aberchane et al.,2001; Bourkhiss et al., 2009).

Based on results from (Hazzit et al 2009), on the same species, the $S$. aureus strain is extremely sensitive with an inhibition zone of 51 $\pm 3.4 \mathrm{~mm}$ while $E$. coli, $P$. aeruginosa and $S$. enterica strains are very sensitive with inhibition zones of $17.8 \pm 1.7,15.2 \pm 1.0$ and $15.6 \pm$ $2.4(\mathrm{~mm})$, respectively.
The difference in inhibition diameters could be due mainly to the chemical composition of the essential oils and other extracts and the antibacterial activity of the latter could mainly be due to the majority compounds.

The results obtained are comparable to those obtained by (Amarti et al., 2010), in a study on the antimicrobial activity of essential oils of $T$. algeriensis and T. ciliatus from Morocco on four bacterial strains including $E$. coli and $S$. aureus, showing that the essential oil of $T$. algeriensis has a high activity on both strains but remains low compared to the essential oil of $T$. ciliatus. This low activity may be due to the presence in the HE of T. algeriensis from $\alpha$-pinene $(20.5 \%)$, from $\beta$-pinene $(8.02 \%)$ and limonene $(4.85 \%)$ known for their low antibacterial activities (Knobloch, 1989).

Thymus oils show an interesting antibacterial activity compared to the concentration used $\left(\begin{array}{ll}1.5 & 1\end{array}\right)$, especially against the bacteria Staphylococcus aureus. Indeed, S. aureus, highly pathogenic strain, has a high sensitivity to this oil. This great antibacterial activity can be related in the case of the Thymus oil to the presence of thymol which is the majority. This phenolic compound is indeed known for its antimicrobial properties (Ettayebi et al., 2000).

In a study by Osman et al. (2009), the ethanolic extract of T. algeriensis showed remarkable activity against the $S$. aureus strain, with an inhibition zone of $11 \mathrm{~mm}$.

The results found in our work are superior to those reported in the work of ( Hazzit et al., 2009), which obtained an oil MIC of $1 \mathrm{mg} / \mathrm{ml}$ for $E$. coli and $S$. entertica. On the other hand, S. aureus had a MIC of less than $0.5 \mathrm{mg} / \mathrm{ml}$. 
Other studies have pointed out that the higher the phenol content, the greater the antimicrobial efficacy; this applies to ethanolic extracts which have a higher antimicrobial capacity compared to the aqueous extracts (Mohammedi et al., 2010). Studies by the World Health Organization and other authors (Dorman and Deans, 2000) have also shown that this constituent has strong antibacterial and antifungal activity against many species, including $S$. aureus, E. coli and Aspergillus sp.

In addition, the sensitivity test of the four strains tested against gentamycin showed very strong activity on $S$. aureus and these results in inhibition zones with a diameter of $33.37 \mathrm{~mm}$, however, this antibiotic exerts an activity different from one strain to another which is explained by a certain degree of resistance developed by the other bacterial strains.

Thymic drying and milling conditions can also be the cause of the absence of antibacterial activity. It is reported by Seidel (2005) that if the plant is known by its content in volatile or thermolabile compounds, it is advisable to freeze the plant material as soon as possible after its collection. It is also recommended to grind it subsequently in a mortar with liquid nitrogen as the grinding is also at the origin of the heat generation responsible for the loss of volatile molecules as well as the decomposition and oxidation of thermolabile molecules (Jones and Kinghorn, 2005).

So, the low activity of the ethanolic extract may be due to the small fraction of essential oils which solubilized in ethanol, the large proportion being lost due to drying and extraction conditions. Finally, the activity of an extract is probably due to the presence of synergy between a number of components, which, when separated, become inactive individually (Sarker et al., 2005). This is interpreted by the fact that plants produce a huge variety of small antibiotic molecules with a wide spectrum of structures such as terpenoid, glycosteroid, flavonoid and polyphenol. However, most of these Small molecules have low antibiotic activity compared to common antibiotics produced by bacteria and fungi.

In general, the essential oil and gentamycin tested are more active against gram positive bacteria than gram negative bacteria, this result can be explained by the richness of the wall of gram positive bacteria in proteins while in gram negative, it is mainly assembled in lipopolysaccharides (LPS), the outer membrane of the latter constitutes an effective permeability barrier. The LPS, thanks to its negative surface charges, prevents the diffusion of hydrophobic molecules, and proteins exclude the passage of hydrophilic molecules of high molecular weight. While gram bacteria positive are less protected against antibacterial agents (Hogan and Kolter, 2002). This seems to have a clear correlation with our results. The results of this study confirmed that it is preferable to use the mixture between the essential oil of $T$. algeriensis and the antibiotic gentamycin in order to have a potential synergistic effect or synergistic additive.

\section{Conclusion}

Algeria, by its geographical location, offers rich and diverse vegetation. A many aromatic and medicinal plants grow spontaneously. To this great diversity of flora, is added a centuries-old tradition of use tof the plants. In Despite the progress made in medicine, several populations, particularly those of rural areas, use plants to treat themselves, either by inaccessibility to drugs prescribed by the modern medicine, either because these plants have given very encouraging therapeutic results during their use.
The use of phytotherapy can be dangerous due to the toxicity of certain plants, which requires precautions to be taken when using it. As well as in this work, the antibacterial effects of the essential oil, ethanolic and aqueous extract of the aerial part of T. hirtus sp. algeriensis were investigated. T. hirtus sp. algeriensis extracts were tested in vitro to reveal their inhibitory power against four bacterial strains.

The essential oil revealed variable antibacterial activities against the bacterial strains tested. However, the ethanolic extract shows a particularly remarkable antibacterial activity on $S$. aureus only. The aqueous extract showed no antibacterial activity. The difference in the inhibition zone between extracts is explained by the influence of several factors: The structure of the bacteria walls, the concentration of extracts, the nature and structure of the active substances in the extracts.

The results we have obtained confirm the powerful antibacterial activity of the essential oil of this species as well as the antibiotic Gentamycin. The combination effect of the essential oil of T. algeriensis and Gentamycin, which has been the objective of our work, shows a very strong activity against the four bacterial strains tested, with an important activity than those of the fractions tested separately.

Despite the encouraging results of this survey concerning phytotherapy, its practice in the EL Kantara region remains limited. Medicinal plants, like medicines, must have strict standard rules that only an herbalist can meet. Thus, more importance must be given to the cultivation, exploitation and marketing of these plants, which can be an important source of external income.

\section{Acknowledgements}

I thank the scientific research team "valorization of the bioresources" under my presidency at the laboratory level of research" genetics, biotechnology and valorization of the bioresources "of the university Mohamed Khider Biskra Algeria.

\section{Conflict of interest}

The author declared that there is no conflicts of interest in the course of conducting the research. The author has final decision regarding the manuscript and decision to submit the findings for publication.

\section{References}

Aberchane, M.; Fechtal, M.; Chaouch, A.; Bouayoune, T. (2001). Influence of the duration and the extraction technique on the yield and quality of the essential oils of Atlas cedar (Cedrusatlantica manetti). Annals of forest research in Morocco ISSN 0483-8009 CODEN AFRMA, 34:110-118.

Afnor (1989). "Water, Methods of Testing," French Association of Standardization, Edition, Paris.

Ait-Ouazzou, A.; Lorán, S.; Arakrak, A.; Laglaoui, A.; Rota, C.; Herrera, A. and Conchello, P. (2012). Evaluation of the chemical composition and antimicrobial activity of Mentha pulegium, Juniperus phoenicea, and Cyperus longus essential oils from Morocco. Food Research International, 45(1):313-319.

Aribi I. (2013). Ethnobotanical study of medicinal plants from the Jijel region: anatomical, phytochemical study and search for biological activities of two species. Memory of Magister, Univ. Houari Boumediène (USTHB), Algiers, pp:69-71.

Asmaa A. and Laaribyia S. (2017). Ethnobotanical and floristic study in rural communes Sehoul and Sidi Abderrazak (case of MaamoraNorthern Morocco) Algerian, Nature and Technology Journal. Flight. B: Agronomic and Biological Sciences, 17:15-24. 
Bekkara, A.; Didi, A; Gherib, M.; Didi, M.A.; Ardestani, A. and Yazdanparast, R. (2007). Chemical composition of the essential oil of Romarins offcinalis L. growing in the spontaneous and cultivated state of the region of Tlemcen. Biology and Health, 7:6-11.

Bahorun, T. (1997). Active natural substances: Mauritian flora, a potential source of supply. AMAS. Food and agricultural research council. Reduced. Mauritius.

Beloued, A. (2001). Medicinal plants of Algeria. 2 Ed. ISBN. Ben Aknoun (Algiers), pp:22-58.

Benhamza, L. (2008). Biological effects of the small knapweed erythraea centaurium (1.). state doctoral dissertation, univ. Mentouri, Constantine, pp:55.

Benlamdini, N.; Elhafian, M.; Rochdi, A. and Zidane, L. (2014). Floristic and ethnobotanical study of the medicinal flora of Haute Moulouya, Morocco. Journal of Applied Biosciences, 78:6771-6787.

Bougatef, A.; Hajji, M.; Balti, R.; Lassoued, I.; Triki-Ellouz, Y. and Nasri, M. (2009). Antioxidant and free radical-scavenging activities of smooth hound (Mustelus mustelus) muscle protein hydrolysates obtained by gastrointestinal proteases. Food Chemistry, 114:1198-1205.

Bourkhiss, M.; Hnach, M.; Bourkhiss, B.; Ouhssine, M.; Chaouch, A.; Satrani, B. (2009). Effect of drying on the content and chemical composition of the essential oils of Tetraclinis articulata (Vahl) Masters. Agrosolutions, 20(1):44-48.

Ebrahimi, S.N.; Hadian, J.; Mirjalili, M.H.; Sonboli,A. and Yousefzadi, M.M. (2008) Essential oil composition and antibacterial activity of Thymus caramanicus at different phenological stages. Food Chemistry, 110(4):927-931.

Casfm (2015). Recommandations du-EUCAST-Comité de l'Antibiogramme de la Société Française de Microbiologie (SFM)-European Committee on Antimicrobial Susceptibility Testing (EUCAST).

Chabrier, J.Y. (2010). Medicinal plants and forms of use in herbal medicine.2006. Studies on the essential oils and antimicrobia activity of Thymus algeriensis Boiss. and Reut. Int. J. Aromatherapy, 16(2):95-100.

Dorman, H.J.D. and Deans, S.G. (2000). Antimicrobial agents from plants: Antimicrobial activity of plant volatile oils. J. Appl. Microbial. 88:308-316.

Ettayebi, K.; El Yamani, J. and Rossihasani, BD. (2000). Synergistic effects of nisin and thymol on antimicrobial activities Listeria monocytogenes and Bacillus subtilis, FEMS Microbial. Lett., 183:191-195.

FAO. (1996). United Nations Food and Agriculture Organization Rome.

Fattouch, S.; Caboni, P.; Coroneo, V., Tuberoso, C.I.; Angioni, A.; Dessi, S.; Marzouki, N. and Cabras, P. (2007). Antimicrobial activity of Tunisian quince (Cydonia oblonga Miller) pulp and peel polyphenolic extracts. J. Agric. Food Chem., 55(3):963-969.

Güllüce, M.; Sökmen, M.; Daferera, D.; Agar, G.; Özkan, H.; Kartal, N.; Polissiou, M.; Sökmen, A., and Sahin, F. (2003). In vitro antibacterial, antifungal and antioxidant activities of the essential oil and methanol extract of herbal parts and callus cultures of Satureja hortensis L. J. Agric. Food Chem., 51:3958-3965.

Hazzit, M.; Baaliouamer, A. and Veríssimo, A.R. (2009). Chemical composition and biological activities of Algerian Thymus oils. Food Chemistry, 116:714-721

Hogan, D and Kolter R. (2002). Why are bacteria refractory to antimicrobials? In: Activité antibactérienne des polyphénols extraits d'une plante médicinale de la flore d'Algérie: Origanum glandulosum Desf. Current pinion in Microbiology, 5:272-274.
Joffin, J.N. and Layeral, G. (2006). Technical microbiology Tom 1. Dictionary of techniques.

Jones, W. P. and Kinghorn, A. D. (2005). Extraction of plant sec ondary metabolites. In: Sarker S. D., Latif Z. and Gray A. I. Natural products isolation. Humana Press (Totowa), pp:323-411.

Kalmetre, G. and Turnidge, D. (2012). Reviving old antibiotics. Journal of Antimicrobial Chemotherapy, 70(8):2177-2181.

Kechkar, M. (2008). Extraction of silymarin and study of its antimicrobial activity. Thesis magister.

Mohammedi, Z; Bachik, S. and Belkaroube, N. (2010). Potentiel antifongique et anti aflatoxinogène des huiles essentielles d'une Thymus fontanesii Boiss and Reut. Les technologies de laboratoire, 5(19):10-15.

Nccls. (2000). Methods for dilution antimicrobial susceptibility tests for bacteria that grow aerobically: Approved standard, 5th ed., NCCLS document M7-A5 (ISBN 1-56238-394-9). NCCLS, Pennsylvania, USA.

Osman, C.; Haag, M.; Potting, C.; Rodenfels, J.; Dip, P.V.; Wieland, F.T.; Brügger, B.; Westermann, B. and Langer T. (2009). The genetic interactome of prohibitins: Coordinated control of cardiolipin and phosphatidylethanolamine by conserved regulators in mitochondria. J. Cell Biol., 184(4):583-596.

Ozenda. (1991). Flora of the Sahara. 2éme Ed. CNRS: pp:622.

Panizzi, L.; Flamini, G; Cioni, P.L. and Morelli, I. (1993). Composition and antimicrobial activity of essential oils of four mediterranean Lamiaceae. J. Ethnopharmacology, 39:167-170.

Ponce, A.G; Fritz, R.; Del Valle, C.E and Roura S.I. (2003). Antimicrobial activity of essential oils on the native microflora of organic Swiss chard. Lebensmittel-Wissenschaft und-Technologie, 36:679-684.

Quezel, P. and Santa, S. (1963). New flora of Algeria and southern desert regions, Volume II. Editions of the National Center for Scientific Research. 15, Quai Anatole-France-Paris $7^{\mathrm{e}}$.

Ribéreau-Gayon P. (1968). Phenolic compounds of plants, Dunod Edition. Paris.

Sarker, S.D.; Latif, Z. and Gray, A.I. (2005). Natural Product Isolation. In: Sarker S. D., Latif Z. and Gray A. I. Natural products isolation. Humana Press (Totowa), pp:1-23.

Seidel, V. (2005). Initial and bulk extraction. In: Sarker S. D., Latif Z. and Gray A. I. Natural products isolation. Humana Press (Totowa), pp:27-37.

Song, J. H. (2008). What's new on the antimicrobial horizon? International Journal of Antimicrobial Agents, 32(4):207-213.

Tabuti, J.R.; Lye, K.A. and Dhillion, S.S. (2003). Traditional herbal drugs of Bulamogi, Uganda: Plants, use and administration. J. Ethnopharmacol., 88(1):19-44.

Tamer, C. A.; Kumral, A.; Asan, M. and Sahin, I. (2007). Chemical compositions of traditional tarhana having different formulations. Journal of Food Processing and Preservation, 31(1):116-126.

Van Den Broucke, C.O. and Lemli, J.A. (1981). Pharmacological and chemical investigation of thyme liquid extracts. Planta Medica, 4:129-135.

Zeghid, N. (2013). Study of the polyphenolic content of two medicinal plants of economic interest (Thymus vulgaris, Rosmarinus officinalis) and evaluation of their antibacterial activity: Memory with a view to obtaining the diploma of magister. Mentouri University. Constantine, pp:9-14.

Citation: Yamina Bouatrous (2019). Antibacterial activity of an essential oil and various extracts of the medicinal plant Thymus hirtus sp algeriensis Boiss. \& Reut. Ann. Phytomed., 8(2):108-114. 